\title{
Floristic Diversity and Important Value Indices of Tree Species in Lower Kanchenjunga Singhalila Ridge Eastern Nepal
}

\author{
Nar Bahadur Khatri Chhetri ${ }^{*}$, Krishna Kumar Shrestha² \\ ${ }^{1}$ Golden Gate International College, Battisputali, Kathmandu, Nepal \\ ${ }^{2}$ Central Department of Botany, Tribhuvan University, Kirtipur, Kathmandu, Nepal \\ Email: ${ }^{*}$ khatrinb26@gmail.com
}

How to cite this paper: Chhetri, N.B.K. and Shrestha, K.K. (2019) Floristic Diversity and Important Value Indices of Tree Species in Lower Kanchenjunga Singhalila Ridge Eastern Nepal. American Journal of Plant Sciences, 10, 248-263.

https://doi.org/10.4236/ajps.2019.101019

Received: December 1, 2018

Accepted: December 12, 2018

Published: January 25, 2019

Copyright (c) 2019 by author(s) and Scientific Research Publishing Inc. This work is licensed under the Creative Commons Attribution International License (CC BY 4.0).

http://creativecommons.org/licenses/by/4.0/

\begin{abstract}
The present paper is based on the finding of floristic diversity inventory research work conducted in Lower Kanchenjungha Singhalila Ridge, in Nepal side of Eastern Himalaya. Knowledge on floristic diversity of an area can reflect the total resources, their use patterns and conservation status which have a key role for making conservation strategies and policies. Analysis of vegetation helps to develop detailed picture of plant communities of that region. A total of 299 plant species belonging to 184 genera and 86 families were found in the Lower Kanchenjungha Singhalila Ridge. Dicotyledonous flora includes 69 families, 150 genera and 229 species whereas Monocotyledonous flora includes 15 families, 32 genera and 39 species. On the basis of floristic analysis Rosaceae was found to be the largest family with 23 species followed by Ericaceae 17, and Lauraceae 9 species. Current study furnishes three new addition to the flora of Nepal viz. Begonia flaviflora H. Hara (Begoniaceae), Carex cruciata Wahlenberg var. argocarpa C. B. Clarke (Cyperaceae), and Strobilanthes helicta Anderson (Acanthaceae). Of this total, 30 woody tree species with 551 individuals and 23 genera were recorded from the altitudinal range of $2100-3000 \mathrm{~m}$ of study area. The highest relative frequency was recorded by Lithocarpus pachyphylla (18.48\%), Symplocos ramosissima (16.30\%), Rhododendron falconeri (13.95\%), Symplocos dryophylla (10.20\%). Eurya acuminata and Symplocos species were found to be dominant in lower elevation whereas Lithocarpus pachyphylla and Rhododendron species were found to be dominant in upper elevation.
\end{abstract}

\section{Keywords}

Eastern Himalaya, Inventory, Plant Specimens, Species Richness, Conservation 


\section{Introduction}

Flora refers to the brief taxonomic treatment of all plants occurring in a geographical location which generates a comprehensive account. A complete flora of country is necessary to reflect the whole plant diversity of that country. Absence of flora severely hinders any scientific inquiry into plants [1]. The Eastern Himalaya is recognized as a global center of species diversity [2] [3]. The high floristic diversity of this area is due to the presence of diverse ecological habitats as well as climatic variations. It is also interesting phytogeographically because of Sino-Japanese and Sino-Himalayan elements. Species richness and endemism are very high in Eastern Himalaya due to the presence two biological niches viz. Indomalayan and Palaeartic realms [4]. The Kanchenjungha complex mostly covers the Taplejung district, the northeastern part of the Nepal, bordered by Sikkim (India) in the east and Tibet (China) in the north. The climate ranges from upper subtropical to alpine. Out of 6500 species of higher plants in Nepal flora, about two-third of the species are expected to occur in this area and the number of species are generally decreased from Central to Western Nepal [5].

Vegetation is an overall expression of various environmental factors which operates gradually or in a cyclic manner. Analysis of vegetation helps to develop detailed picture of plant communities of geographical location. More deliberatively vegetation refers to the expression of total plants cover in an area which may be made up of one or more plant communities or aggregation of plants usually forming a mosaic or complex [6]. The structure of tree species diversity in hill forest varies greatly from place to place due to variation of altitude, orientation of slope, nature of soil and type and intensity of disturbance [7].

Change in vegetation type occurs not only with respect to altitude, latitude, slope and soil but also with respect to rainfall pattern and human impacts such as natural disturbances like forest fire, soil erosion, landslide, volcanic activity etc. The climatic change determines forest dynamics and tree diversity [8]. Disturbance may increase species richness in old growth forest and may maintain species diversity [9]. Higher species richness is maintained in intermediate level of disturbance [10].

\section{Materials and Methods}

\subsection{Study Area}

Ilam is a small hilly district located in Eastern Development Region of Nepal with an area of $1703 \mathrm{sq}$. km. extending from $26^{\circ} 4^{\prime} \mathrm{N}-27^{\circ} 8^{\prime} \mathrm{N}$ latitude and $87^{\circ} 40$ E - $88^{\circ} 10^{\prime} \mathrm{E}$ longitude. The present study area Lower Kanchenjungha Singhalila Ridge covers the four eastern VDCs of Ilam district viz. Maimajuwa, Mabu, Jamuna, and Jogmai. This region enjoys a temperate climate characterized by the monsoon, which deposits most of the annual precipitation between June and October. The mountain sides are steep, and landslides are not uncommon during the monsoon season. Because of the extreme topography, because clouds and fog commonly block the sky throughout the year, so direct sunlight is limited. 
The climate of this area is characterized by high rainfall, cool and humid atmosphere. Figure 1 reveals the map of the study area.

\subsection{Data Collection}

Two extensive field visits were conducted from June to July, 2007 as pre-monsoon and during September to October 2007 as post-monsoon. Pre-monsoon collection was focused for collection of specimens in flowering stages and other collection was focused in fruiting stages. Plants specimens were collected by two botanical expeditions. Triplicate specimens of each species were collected as far as possible. The route of collection and area has been shown in the GIS map. The collected voucher specimens were properly tagged in the field during collection with appropriate field notes. The collected specimens were dried and mounted on herbarium sheets of $(28 \times 44 \mathrm{~cm})$. The specimens were prepared and managed using techniques mentioned in the Herbarium handbook [11]. The identification of collected plant specimens were done by using relevant literatures such as [12] [13] [14]. Similarly, plants were identified in the field by consulting the books [15] [16] under the supervision of senior taxonomist Professor Doctor Krishna Kumar Shrestha Central Department of Botany Tribhuvan University Nepal. The specimens were further confirmed by cross tallying with the specimens deposited at National Herbarium and Plant Laboratories (KATH), Godawari and Tribhuvan University Central Herbarium, Kirtipur (TUCH). The dried plant specimens were mounted in $(28 \times 44 \mathrm{~cm})$ sheet. The process of herbarium preparation is based on the herbarium technique developed by Bridson. The

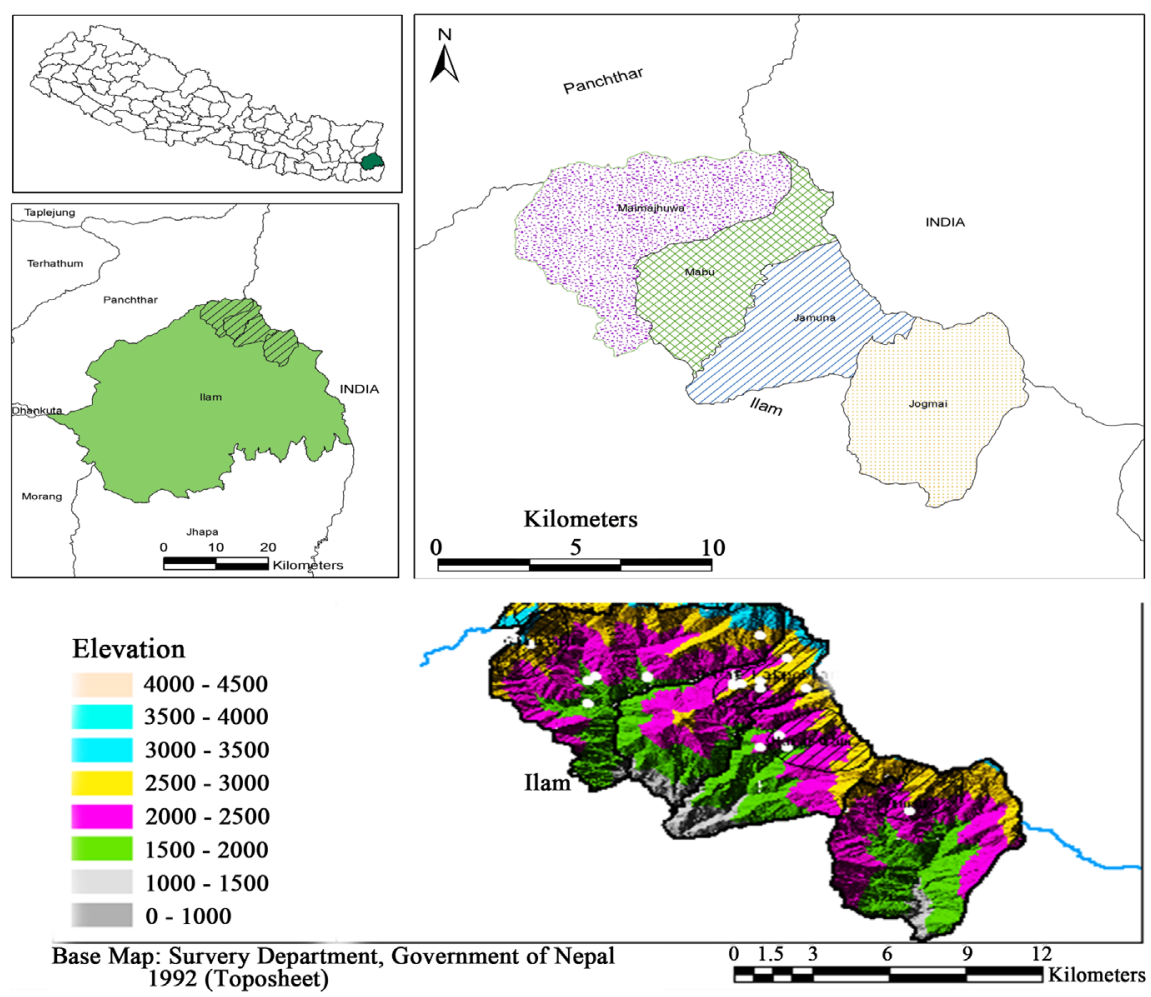

Figure 1. Map of study area. 
dried specimens were deposited at National Herbarium and Plant Laboratories (KATH), Godavari, and Tribhuvan University Central Herbarium, Kirtipur (TUCH).

A total of 50 macro plots of $10 \mathrm{~m} \times 10 \mathrm{~m}$ were laid down in three different altitudinal ranges. Altogether 30 tree species were recorded from three elevation ranges, 19 from lower elevation, 20 from middle elevation and 22 from upper elevation. The whole temperate forest of the study area was resolved into three sub zones [17] [18] to carry the quantitative vegetation analysis of the plant communities along an altitudinal gradient.

- Lower Temperate Zone (LTZ): It ranges from the elevation 2100 - $2400 \mathrm{~m}$.

- Middle Temperate Zone (MTZ): It ranges from the elevation of $2400-2700$ $\mathrm{m}$.

- Upper Temperate Zone (UTZ): It ranges from the elevation of $2700-3000 \mathrm{~m}$.

\subsection{Data Analysis}

Vegetation analysis of the selected forest stands along an altitudinal gradient was carried out by using square quadrats by following stratified-random sampling method [19]. The quadrat of $10 \mathrm{~m} \times 10 \mathrm{~m}$ sized were laid down for sampling of trees. In each $10 \mathrm{~m} \times 10 \mathrm{~m}$ quadrats the number of individual trees $\mathrm{DBH}$ [diameter at breast height $1.37 \mathrm{~m}, \mathrm{dbh} \geq 10 \mathrm{~cm}$ ] of each species was noted. The height of each tree was estimated with the help of Clinometer. Herbarium specimens were prepared for collected plants. Quantitative data were gathered with the help of field data sheet and quantitatively analyzed for abundance, density and frequency according to the formulae given by Mishra [20]. The relative values were summed up to represent importance value index (IVI) as reported by Curtis [21]. The diversity index $\left(H^{\prime}\right)$ was computed by using Shannon-Wiener information Index [22]. The concentration of dominance (CD) was computed by Simpson's Index [23]. For prediction of regeneration behavior of tree species size class distribution was developed. All the trees were divided into dbh classes of $10 \mathrm{~cm}$ interval and density of tees in each diameter class was calculated and size class distribution diagram was developed.

\section{Results}

\subsection{Floristic Composition}

Present study recorded 299 species among them seven species were identified only family level, 22 species only generic level rest of them to species level falling under 184 genera and 86 families. Dicots belong to 69 families, 150 genera and 229 species whereas Monocots include 15 families with 32 genera and 39 species. Similarly, Gymnosperms represented two families, two genera and two species. Figure 2 shows the complete picture of the result.

Floristic analysis showed that Rosaceae as the largest family having 23 (8.24\%) species and followed by Ericaceae 17 (6.09\%), Lauraceae 9 (2.90\%), Urticaceae, Labiateae, Scrophulariaceae, Asteraceae 8 (2.87\%) of species. Similarly, Ranunculaceae, 


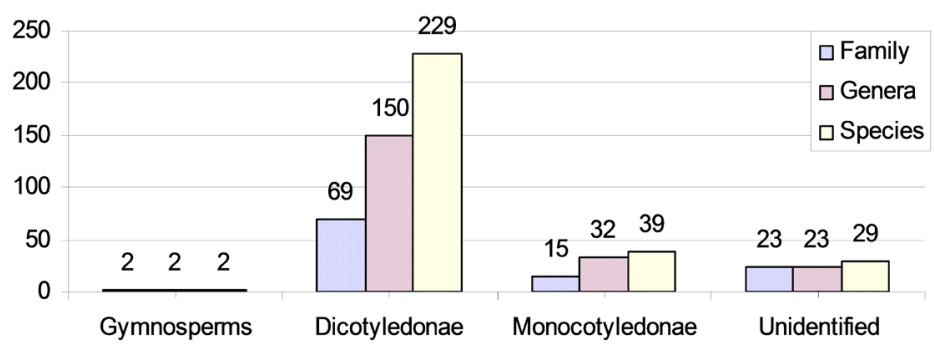

Figure 2. Number of family, genera and species recorded from study area.

Orchidaceae, Convallariaceae, Urticaceae 7 (2.51\%) species and so on. The two genera Rhododendron and Rubus were found to be largest genera constituting 8 species in each. Present study has three additional new records of species to flora of Nepal. The newly recorded species are not published in available Nepali literatures till now (Table 1). Eleven threatened and one endemic plant species mentioned (Table 2).

The study includes 11 threatened species as follows: Taxus wallichiana (IUCN-V, CITES-II, GoN-II), Swertia chirayita (IUCN-V), Podophyllum hexandrum (IUCN-V), Paris polyphylla subsp polyphylla (IUCN-V), Paris polyphylla subsp marmorata (IUCN-V), Michelia velutina (CITES-II), Michelia champaca (IUCN-E, CITES II, GoN-III), Magnolia globosa (IUCN-R, CITES-II), Magnolia campbelli (IUCN-R, CITES II), Dioscorea deltoidea (IUCN-CT, CITES-II), Aconitum spicatum (IUCN-CT). Due to the anti-cancer properties of Taxus, it is highly exploited similarly the Michelia species are also exploited in natural forest due to the high timber value. Shrestha (2002) assessed floral diversity of Kanchenjungha conservation area at landscape level was for resource management strategy.

\subsection{Community Structure in Three Zones}

The whole study side was site which includes temperate Zone was resolved in three sub zones on the basis of elevation ranges.

\section{Lower temperate zone $(2100-2400 \mathrm{~m})$}

In this range Symplocos ramosissimashowed the highest frequency (63.64\%) and relative frequency $14.29 \%$. The lowest frequency and relative frequency were 9.09\% and $2.04 \%$ respectively. Likewise, the density of individual tree species ranged from $263.64 \mathrm{plant} / \mathrm{ha}-9.09 \mathrm{plant} / \mathrm{ha}$. The total density of all tree species was $1109.09 \mathrm{plant} / \mathrm{ha}$. The dominance of the individual tree species ranged from $15.31 \mathrm{~m}^{2} / \mathrm{ha}-0.07 \mathrm{~m}^{2} / \mathrm{ha}$. Similarly the important value index was found to be highest for Eurya acuminate (39.72) and followed by Symplocos. ramosissima (38.72), while the other species likes Lindera, Rhus showed least IVI (2.94). In this range canopy was dominated Quercus lamellosa, Castanopsis hystrix, Lithocarpus pachyphylla and Persea odoratissima but sub-canopy was well dominated by Eurya acuminata and Symlocos species. Altogether 19 tree species were recorded from this zone. Table 3 shows the quantitative vegetation analysis of lower temperate zone. 
Table 1. New addition to flora of Nepal recorded from LKSR, eastern Nepal.

\begin{tabular}{|c|c|c|c|c|c|c|c|}
\hline Call No. & Family & Species Name & Coll. date & Alt. (m) & Lat & Long & Locality \\
\hline B 157 & Begoniaceae & Begonia flaviflora $\mathrm{H}$. Hara & $06 / 07$ & 2245 & 27.04 & 88.00 & Jamuna 2, Hangetham, Ilam \\
\hline C 240 & Cyperaceae & $\begin{array}{l}\text { Carex cruciata Wahlenberg } \\
\text { var. argocarpa C. B. Clarke }\end{array}$ & $09 / 12$ & 3210 & 2718 & 88.01 & Bie-Chitre, \\
\hline C 191 & Acanthaceae & Strobilanthes helicta Anderson & 09/05 & 2656 & $27^{\circ} 40^{\prime} 7$ & $87^{\circ} 59^{\prime} 37$ & Dobate, Hangetham, Ilam \\
\hline
\end{tabular}

Table 2. List of threatened and endemic plant species recorded from LKSR.

\begin{tabular}{rrrccc}
\hline S. N. & Record & & Species Name with threatened category & Alt. (m) & Locality \\
\hline 1 & Threatened & Ranunculaceae & Aconitum spicatum (IUCN-CT) & 3170 & Chhintapu, Maimajuwa 7 \\
2 & Threatened & Dioscoreaceae & Dioscorea deltoidea (IUCN-CT, CITES-II) & 2005 & Hangetham, Jamuna-1 \\
3 & Threatened & Magnoliaceae & Magnolia campbelli (IUCN-R, CITES II) & 3220 & Chhintapu, Maimajuwa 7 \\
4 & Threatened & Magnoliaceae & Magnolia globosa (IUCN-R, CITES-II) & 2040 & Maimajuwa 7, Naule Gaun, Ilam \\
5 & Threatened & Magnoliaceae & Michelia champaca (IUCN-E, CITES II, GoN-III) & 2050 & Newa khola, Mai majhuwa \\
6 & Threatened & Magnoliaceae & Michelia velutina (CITES-II) & 1870 & Newa khola, Mai majhuwa, Ilam \\
7 & Threatened & Trilliaceae & Paris polyphylla subsp marmorata (IUCN-V) & 2665 & Dobate, Mabu-8 \\
8 & Threatened & Trilliaceae & Paris polyphylla subsp polyphylla (IUCN-V) & 3060 & Mabu, Near Mai khola, Chauri chowk, Ilam \\
9 & Threatened & Podophyllaceae & Podophyllum hexandrum (IUCN-V) & 3225 & Mabu, Bikhe Bhanjyang, Ilam \\
10 & Threatened & Gentianaceae & Swertia chirayita (IUCN-V) & 2042 & Maimajuwa 7, Naule Gaun \\
11 & Threatened & Taxaceae & Taxus wallichiana (IUCN-V, CITES-II, GoN-II) & 3220 & Chhintapu,Maimajuwa 7 \\
12 & Endemic & Umbelliferae & Heracleum lallii & 1974 & Sisne, Mai majhuwa \\
\hline
\end{tabular}

Source: IUCN. 1987/CITES. 1995.

Table 3. Frequency (F\%), Relative Frequency (RF), Density (D), Relative Density (RD), Basal area (BA), Relative Basal Area (RBA) and Importance Value Index (IVI) of Tree species in lower temperate zone.

\begin{tabular}{|c|c|c|c|c|c|c|c|}
\hline Species name & F\% & RF\% & $\mathrm{D} \cdot \mathrm{ha}^{-1}$ & RD \% & $\mathrm{BAm}^{2} \cdot \mathrm{ha}^{-1}$ & RBA \% & IVI \\
\hline Acer campbellii & 14.29 & 4.35 & 17.86 & 1.48 & 5.64 & 5.22 & 11.05 \\
\hline Alangium alpinum & 3.57 & 1.09 & 3.57 & 0.30 & 0.03 & 0.03 & 1.41 \\
\hline Daphniphyllum himalense & 14.29 & 4.35 & 139.29 & 11.57 & 0.41 & 0.38 & 16.30 \\
\hline Eurya acuminata & 17.86 & 5.43 & 53.57 & 4.45 & 2.92 & 2.70 & 12.59 \\
\hline Lindera neesiana & 3.57 & 1.09 & 3.57 & 0.30 & 0.06 & 0.06 & 1.44 \\
\hline Lithocarpus pachyphylla & 60.71 & 18.48 & 289.29 & 24.04 & 56.28 & 52.09 & 94.60 \\
\hline Lindera neesiana (Siltimur) & 3.57 & 1.09 & 3.57 & 0.30 & 0.07 & 0.07 & 1.45 \\
\hline Lyonia ovalifolia & 42.86 & 13.04 & 210.71 & 17.51 & 8.15 & 7.55 & 38.10 \\
\hline Magnolia campbellii & 17.86 & 5.43 & 17.86 & 1.48 & 5.17 & 4.79 & 11.70 \\
\hline Michelia dltlsopa & 3.57 & 1.09 & 3.57 & 0.30 & 0.29 & 0.27 & 1.65 \\
\hline Myrsine semiserata & 10.71 & 3.26 & 25.00 & 2.08 & 1.87 & 1.73 & 7.07 \\
\hline Neolitsea cuipala & 3.57 & 1.09 & 3.57 & 0.30 & 2.27 & 2.10 & 3.49 \\
\hline Patpate & 10.71 & 3.26 & 21.43 & 1.78 & 1.32 & 1.22 & 6.26 \\
\hline Persea odoratissima & 14.29 & 4.35 & 14.29 & 1.19 & 0.56 & 0.51 & 6.05 \\
\hline Quercus glauca & 7.14 & 2.17 & 7.14 & 0.59 & 0.99 & 0.92 & 3.68 \\
\hline Quercus lamellosa & 14.29 & 4.35 & 35.71 & 2.97 & 3.22 & 2.98 & 10.29 \\
\hline Rhododendron falconeri & 14.29 & 4.35 & 42.86 & 3.56 & 1.53 & 1.42 & 9.33 \\
\hline Symplocos glomerata & 10.71 & 3.26 & 64.29 & 5.34 & 4.30 & 3.98 & 12.58 \\
\hline Symplocos ramosissima & 53.57 & 16.30 & 232.14 & 19.29 & 12.69 & 11.74 & 47.33 \\
\hline Taxus wallichiana & 7.14 & 2.17 & 14.29 & 1.19 & 0.28 & 0.26 & 3.62 \\
\hline Total & 328.57 & 100.00 & 1203.57 & 100.00 & 108.06 & 100.00 & 300.00 \\
\hline
\end{tabular}




\section{Middle temperate zone (2400 - $2700 \mathrm{~m})$}

Lithocarpus pachyphylla was the highest frequency was achieved as $60.71 \%$ and relative frequency $8.48 \%$. Similarly, the lowest frequency and relative frequency achieved as $3.57 \%$ and $1.09 \%$ respectively. Middle temperate forest is well dominated by Lithocarpus pachyphylla with its highest IVI value 94.60 and codominated by Symplocos ramosissima (47.33) and the species such as Magnolia and Michelia showed very scanty presence with least IVI values. In this site the density of individual tree species ranged from $289.29 \mathrm{plant} / \mathrm{ha}-3.75 \mathrm{plant} / \mathrm{ha}$. While total density of all tree was found to be 1203.57 plant/ha. Likewise the dominance of tree species ranged from $56.28 \mathrm{~m}^{2} / \mathrm{ha}-0.03 \mathrm{~m}^{2} / \mathrm{ha}$. In this zone Lithocarpus (Bante) formed the very well canopy up to $25 \mathrm{~m}$. Consequently Symplocos sp, Lyonia ovalifolia, Rhododendron falconerii made the sub canopy. Altogether 20 tree species were recorded from this site. Table 4 shows quantitative vegetation analysis of middle temperate zones.

Table 4. Frequency (F\%), Relative Frequency (RF), Density (D), Relative Density (RD), Basal area (BA), Relative Basal Area (RBA) and Importance Value Index (IVI) of Tree species in lower temperate zone.

\begin{tabular}{|c|c|c|c|c|c|c|c|}
\hline Name of species & $\mathrm{F} \%$ & $\mathrm{RF} \%$ & $\mathrm{D} \cdot \mathrm{ha}^{-1}$ & RD \% & $\mathrm{BAm}^{2} \cdot \mathrm{ha}^{-1}$ & RBA \% & IVI \\
\hline Acer pectinatum & 27.27 & 6.12 & 54.55 & 4.92 & 15.31 & 15.99 & 27.03 \\
\hline Alangium alpinum & 9.09 & 2.04 & 9.09 & 0.82 & 0.12 & 0.13 & 2.99 \\
\hline Bhadrase & 9.09 & 2.04 & 9.09 & 0.82 & 5.16 & 5.39 & 8.25 \\
\hline Castanopsis hystrix & 36.36 & 8.16 & 109.09 & 9.84 & 3.10 & 3.23 & 21.23 \\
\hline Castanopsis tribuloides & 9.09 & 2.04 & 72.73 & 6.56 & 5.23 & 5.46 & 14.06 \\
\hline Cryptomeria japonica & 9.09 & 2.04 & 9.09 & 0.82 & 0.14 & 0.15 & 3.01 \\
\hline Daphniphyllum himalaynse & 9.09 & 2.04 & 9.09 & 0.82 & 5.41 & 5.65 & 8.51 \\
\hline Eurya acuminata & 45.45 & 10.20 & 263.64 & 23.77 & 5.42 & 5.66 & 39.64 \\
\hline Lindera neesiana & 9.09 & 2.04 & 9.09 & 0.82 & 0.07 & 0.07 & 2.94 \\
\hline Lithocarpus pachyphylla & 27.27 & 6.12 & 45.45 & 4.10 & 9.88 & 10.32 & 20.55 \\
\hline Lyonia ovalifolia & 36.36 & 8.16 & 100.00 & 9.02 & 3.71 & 3.88 & 21.06 \\
\hline Myrsine semiserata & 18.18 & 4.08 & 18.18 & 1.64 & 1.00 & 1.05 & 6.77 \\
\hline Neolitsea cuipala & 18.18 & 4.08 & 18.18 & 1.64 & 4.97 & 5.20 & 10.92 \\
\hline Persea odoratissima & 27.27 & 6.12 & 54.55 & 4.92 & 6.80 & 7.11 & 18.15 \\
\hline Quercus glauca & 9.09 & 2.04 & 9.09 & 0.82 & 0.45 & 0.47 & 3.33 \\
\hline Quercus lamellosa & 27.27 & 6.12 & 45.45 & 4.10 & 15.37 & 16.06 & 26.28 \\
\hline Rhus succedanea & 9.09 & 2.04 & 9.09 & 0.82 & 0.12 & 0.13 & 2.99 \\
\hline Symplocos dryophila & 45.45 & 10.20 & 90.91 & 8.20 & 4.98 & 5.20 & 23.60 \\
\hline Symplocos ramasissima & 63.64 & 14.29 & 172.73 & 15.57 & 8.49 & 8.86 & 38.72 \\
\hline Total & 445.45 & 100.00 & 1109.09 & 100.00 & 95.74 & 100.00 & 300.00 \\
\hline
\end{tabular}




\section{Upper temperate zone (2700 - $3000 \mathrm{~m})$}

Lithocarpus pachyphylla showed the highest frequency and relative frequency achieved as $63.64 \%$ and $16.28 \%$. Likewise, the lowest frequency and relative frequency as $9.09 \%$ and $2.33 \%$ respectively. Lithocarpus pachyphylla was well canopy dominating species in this range with maximum IVI 78.8 and codominated by Rhododendron falconerii with IVI value 40.14 and Quercus lamellosa. Other species like Taxus wallichiana, Michelia and Magnolia showed scanty in distribution. The density of individual tree species ranged from 245.45 plant/ha - 9.09 plants/ha, while total tree density for all tree species was found to be 1009.09 plant/ha. Consequently, the dominance ranged from $68.48 \mathrm{~m}^{2} / \mathrm{ha}-0.3 \mathrm{~m}^{2} / \mathrm{ha}$ for individual tree species. In this site Lithocarpus pachyphylla was monodomianat canopy forming plant up to $30 \mathrm{~m}$. Altogether 22 tree species were recorded from this site. Table 5 shows quantitative vegetation analysis of upper temperate zone.

Table 5. Frequency (F\%), Relative Frequency (RF), Density (D), Relative Density (RD), Basal area (BA), Relative Basal Area (RBA) and Importance Value Index (IVI) of Tree species in lower temperate zone.

\begin{tabular}{cccccccc}
\hline Species name & $\mathrm{F} \%$ & $\mathrm{RF} \%$ & $\mathrm{D} \cdot \mathrm{ha}^{-1}$ & $\mathrm{RD} \%$ & $\mathrm{BAm}^{2} \cdot \mathrm{ha}^{-1}$ & $\mathrm{RBA} \%$ & $\mathrm{IVI}$ \\
\hline Castanopsis tribuloides & 9.09 & 2.33 & 9.09 & 0.90 & 0.10 & 0.07 & 3.30 \\
Daphniphyllum himalaynse & 9.09 & 2.33 & 245.45 & 24.32 & 0.20 & 0.14 & 26.79 \\
Eurya acuminata & 18.18 & 4.65 & 27.27 & 2.70 & 0.11 & 0.08 & 7.43 \\
Ilex fragilis & 18.18 & 4.65 & 18.18 & 1.80 & 0.38 & 0.27 & 6.72 \\
Lindera neesiana (Siltimur) & 9.09 & 2.33 & 9.09 & 0.90 & 3.81 & 2.71 & 5.94 \\
Lithocarpus pachyphylla & 63.64 & 16.28 & 136.36 & 13.51 & 68.48 & 48.73 & 78.53 \\
Litsea sericea & 9.09 & 2.33 & 9.09 & 0.90 & 0.14 & 0.10 & 3.33 \\
Litsea cubela & 9.09 & 2.33 & 9.09 & 0.90 & 0.14 & 0.10 & 3.33 \\
Lyonia ovalifolia & 9.09 & 2.33 & 18.18 & 1.80 & 15.23 & 10.84 & 14.97 \\
Magnolia campbellii & 18.18 & 4.65 & 27.27 & 2.70 & 3.26 & 2.32 & 9.67 \\
Michelia velutina & 9.09 & 2.33 & 18.18 & 1.80 & 1.56 & 1.11 & 5.23 \\
Neolitsea cuipala & 27.27 & 6.98 & 27.27 & 2.70 & 0.15 & 0.11 & 9.79 \\
Persea odoratissima & 9.09 & 2.33 & 9.09 & 0.90 & 0.14 & 0.10 & 3.33 \\
Quercus glauca & 18.18 & 4.65 & 18.18 & 1.80 & 0.54 & 0.39 & 6.84 \\
Quercus lamellosa & 9.09 & 2.33 & 9.09 & 0.90 & 34.27 & 24.39 & 27.61 \\
Rhododendron arboreum & 9.09 & 2.33 & 90.91 & 9.01 & 0.24 & 0.17 & 11.51 \\
Rhododendron falconeri & 54.55 & 13.95 & 190.91 & 18.92 & 10.22 & 7.27 & 40.14 \\
Symplocos glomerata & 18.18 & 4.65 & 27.27 & 2.70 & 0.03 & 0.02 & 7.38 \\
Symplocos ramosissima & 27.27 & 6.98 & 63.64 & 6.31 & 1.19 & 0.85 & 14.13 \\
Taxus wallichiana & 18.18 & 4.65 & 18.18 & 1.80 & 0.05 & 0.04 & 6.49 \\
Viburnum cylindricum & 9.09 & 2.33 & 18.18 & 1.80 & 0.18 & 0.13 & 4.26 \\
Viburnum erubescens & 9.09 & 2.33 & 9.09 & 0.90 & 0.09 & 0.06 & 3.29 \\
\hline & 390.91 & 100.00 & 1009.09 & 100.00 & 140.52 & 100.00 & 300.00 \\
\hline Total & & & & & & &
\end{tabular}




\subsection{Species Richness and Diversity Indices}

The combined form of species richness and species evenness is simply meant the Species diversity and the number of individuals per sampling units. Species richness while the distribution of individuals among the species called Species evenness. Evenness becomes maximum when all the species have same or nearly equal number of individuals. Species diversity can be expressed in single index number. Among the several indices most commonly used two indices are Simpson's index and Shannon-Wiener's index [22]. Simpson's index (C) reflects the dominance because it is more sensitive to the most abundant species than the rare species. Following relations were used to calculate Simpson's and Shannon-Weiner indices following Barbour et al. [24].

$$
\begin{aligned}
& \text { Simpson's index of dominance }(C)=\sum_{i=1}^{s}\left(p_{i}\right)^{2} \\
& \text { Shannon -Wiener's index }(H)=-\sum_{i=1}^{s}\left(p_{i}\right)\left(\ln p_{i}\right)
\end{aligned}
$$

where $s=$ total number of species

$p_{i}=$ proportion of all individuals in the sample that belongs to species $i$.

\section{Beta $(\beta)$ Diversity and Similarity Index}

The calculation of Beta $(\beta)$ diversity helps to know the extent of species turn over between the sites. The Whittaker's $\beta$ diversity $\left(\beta_{w}\right)$ was calculated using the following formula [25].

$$
\beta_{w}=s / \bar{\alpha}-1
$$

where $s=$ Total number of species recorded in both sites.

$\bar{\alpha}=$ average of total number of species recorded in two sites.

The value of $\beta$ diversity ranges from 0 (complete similarity) to 1 (complete dissimilarity) for two sites.

\section{Similarity Index (\%)}

Degree of similarity between any two stands can be determined through the use of community coefficient (similarity index) which depends on the quantitative phytosociological characters of species common to both stands. Higher the index value more similar will be the stands to each other. Following are the formula for calculating similarity index.

$$
\text { Sorensen's Similarity Index }\left(\mathrm{IS}_{\mathrm{S}}\right)=\frac{2 C}{A+B} \times 100
$$

where IS $=$ index of similarity

$A=$ Total number of species in one community

$B=$ Total number of species in another community

$C=$ the number of species which occur in both community

The similarity index ranges from $0 \%$ to $100 \%$ to quantify the range from no similarity to complete. It is mentioned in Table 6.

Similarity, the value for tree species richness was achieved highest for lower temperate zone (5.27) and lowest in middle temperate zone (3.29) while upper 
Table 6. Species richness (S), Simpson's index of Dominance (C), Shanon-weiner's index $(H)$. and Beta diversity $(\mathrm{Bw})$.

\begin{tabular}{ccccccc}
\hline Diversity Indices & LTZ & MTZ & UTZ & Beta diversity (Bw) & MTZ & UTZ \\
\hline Simpson's index of Dominance (C) & 0.12 & 0.15 & 0.13 & LTZ & 0.28 & 0.37 \\
Shanon-Weiner's index $\left(H^{\prime}\right)$ & 3.50 & 3.22 & 3.68 & & & \\
Species richness (S) $/ 100 \mathrm{~m}^{2}$ & 5.27 & 3.29 & 3.45 & MTZ & & 0.24 \\
\hline
\end{tabular}

temperate zone showed (3.45) per $100 \mathrm{~m}^{2}$. Similarly, the Simpson's index of Dominance $(C)$ was highest for stand MTZ (0.15) followed by stand UTZ (0.13) and LTZ (0.12). Shanon-Weiner's index $(H)$ was maximum for UTZ (3.68) followed by LTZ (3.50) and MTF (3.22). The Whittaker's beta diversity value shows maximum between LTZ and UTF (0.37) followed by LTZ and MTZ (0.28) and (0.24) between MTZ and UTZ. Similarity index between MTZ \& site UTZ was highest $76.19 \%$ while it was least between site LTF \& site UTF $63.41 \%$ and $71.79 \%$ in between LTZ and MTZ. Similarity index between MTZ \& site UTZ was highest $76.19 \%$ while it was least between site LTF\& site UTF $63.41 \%$ and $71.79 \%$ in between LTZ and MTZ. It is expressed in Table 7.

\section{Size class distribution}

In each sites the tree species were classified into ten size classes with an interval of $10 \mathrm{~cm} \mathrm{dbh}$. Then the density diameter curves were developed to assess the general population structure of tree in three study sites. As shown in the given Figures 3-5 respectively.

\section{Discussion}

\subsection{Floristic Composition}

Flora governs the key position among the natural resources of any geographical area. Study on floristic composition of any region gives the clear picture of floristic content, which in turn can be useful for developing strategy for conservation and management of biodiversity. Eastern Nepal is unique in species diversity as it as the supplementary zone for Eastern Himalaya. The Eastern Himalaya stands out as being one of the globally important sites representing the important hotspot of South Asia. Eastern Himalaya of Nepal has been identified as one of the rich biodiversity hot spot in the world with high species diversity and high level of endemism. Floristic composition has been carried out to enumerate and prepare the comprehensive description of the vascular plants from the Lower Kanchenjungha Singhalila Ridge Ilam district east, Nepal. The variation in altitudinal range and climatic conditions favours the diversity of flora. The genera Rhododendron and Rubus both consisted of 8 species were found to be largest genera and Begonia with 6 species followed by Sorbus, Hypericum, and Berberis with 5 species in each. The floristic analysis showed that the dicotyledonae was dominant in comprision to the monocotyledoneae. The ratio of Monocotyledoneae to Dicotyledoneae was found to be 1:5.95 for species, 1:4.56 for genera and 1:5 for families. Siwakoti and Varma [26] recorded 743 species of flowering 


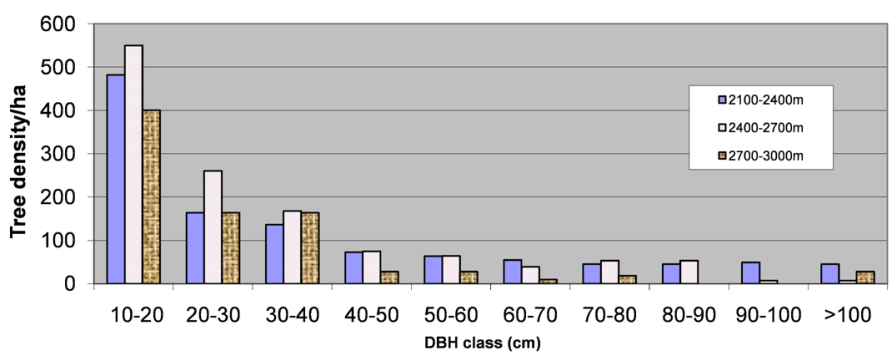

Figure 3. Size class distribution.

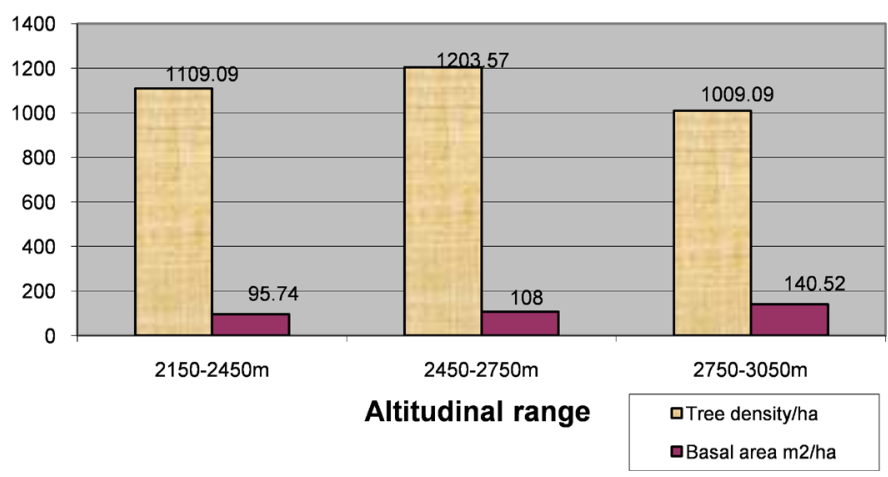

Figure 4. Density/ha and basal area in three altitudinal zone.

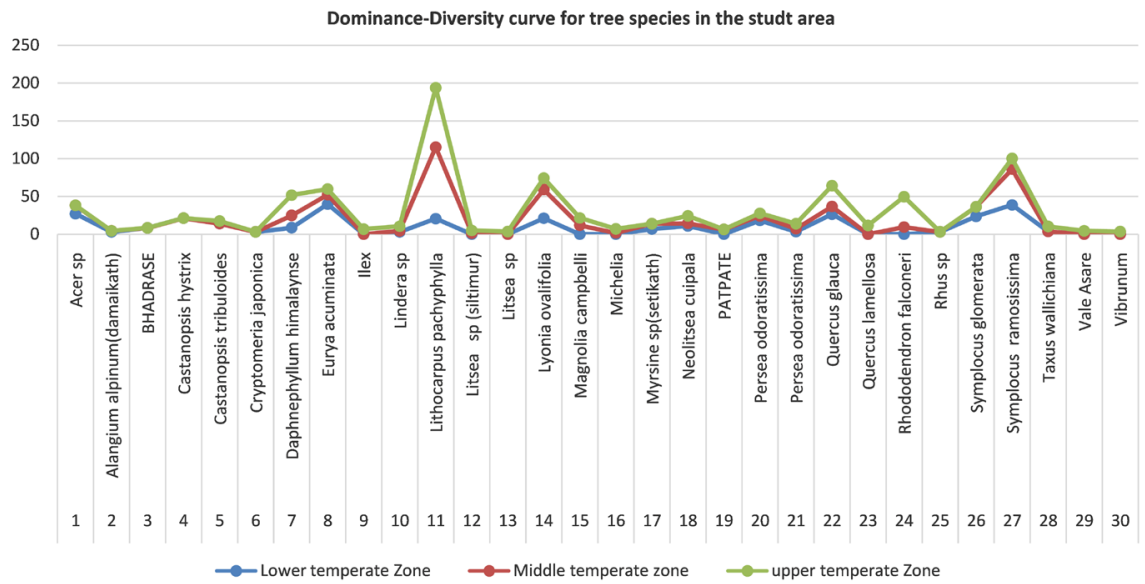

Figure 5. Dominance diversity curve for tree species.

Table 7. Similarity index among three zones.

\begin{tabular}{ccc}
\hline Index of Similarity (IS) & MTZ & UTZ \\
\hline LTZ & 71.79 & 63.41 \\
MTZ & & 76.19 \\
\hline
\end{tabular}

plants belonging to 493 genera and 128 families (dicotyledons 546 species under 383 genera and 105 families of monocotyledons 197 species under 110 genera and 23 families) from eastern Terai whereas in comparison with this present result Siwakoti and Varma reported $42 \%$ of dicots and $20 \%$ of monocots respectively. 
Present study has furnished some new addition to the flora of Nepal. Out of the identified 273 species, three species viz. Begonia flaviflora H. Hara (Begoniaceae), Carex cruciata Wahlenberg var. argocarpa C. B. Clarke (Cyperaceae), and Strobilanthes helicta Anderson (Acanthaceae). Several species still remaining unidentified, which is due to insufficient literature, lack of represented herbarium specimens in KATH and TUCH, etc. This proves that through deep investigation of these areas will increase the chance of new records to the flora of Nepal. The diversity of dicots is nearly five times greater than monocots it is due to the flowering and fruiting.

\subsection{Structure of the Vegetation}

Forest is a complex ecological system in which trees are dominant life forms. Today forest is any land managed for the diverse purposes of forestry, whether or not covered with trees, shrubs, climbers or such other vegetation. Forest represents the largest most complex and most self generating of all ecosystems.

Practices for removal of forest biomass in the form of grazing, lopping, surface burning and litter removal at a given time are a continuous disturbance affecting the stability of the ecosystem and retarding the succession processes in the area. These areas can be clearly demarcated on the basis of different phytosociological parameters of the vegetation. In the present study the tree density ranged from 1009.09 to 1203.57 individuals $\mathrm{ha}^{-1}$, which is comparable to tropical forests. Higher anthropogenic disturbances in the buffer area have also led to the elimination of seedlings of most of the species. The total basal area across the sites ranged from 95.74 to $140.52 \mathrm{~m}^{2} / \mathrm{ha}$. The differences in basal area of tree layer among study sites may be due to difference in altitude, species composition, age of trees, and degree of disturbance and succession stages of the stands. The value obtained for basal area in the present study is comparable to the Indian tropical forests [27]. Importance value index of Lithocarpus pachyphylla as the present study area is located at altitude ranged from $2100 \mathrm{~m}-3000 \mathrm{~m}$. The change in IVI of Lithocarpus pachyphylla among the study sites is due to the change in species composition, disturbance and altitude. Other studies elsewhere have reported a similar range of species richness [28]. Importance value index (IVI) of tree species indicated that Lithocarpus pachyphylla and Eurya acuminata were the dominant species at all the study sites in the tree and sapling layers of tree serve followed by Rhododendron, Lyonia, Acer species, etc.

\subsection{Size Class Distribution}

In the study the size class distribution doesn't indicate different population structure, which may be related to differences in environment and disturbance regimes. The reverse J-shaped size class distribution of trees in a community indicates sustainable regeneration [29]. Although a clear inverse J-shaped graph is absent in present work, but the population structure of middle temperate zone shows somewhat continuous regeneration than others two range. The regenera- 
tion potential of trees in the study area was somewhat in continuous. The different shape of density-diameter shows the extent of effect of disturbances on the density dbh classes [30]. In a montane rain forest in Mexico, Ramierz-Marcial et al. [31] found that stem density decreases with disturbance intensity. Our study also found that the stem density declined with increasing disturbance such as grazing damages sapling through trampling and browsing [32]. Dbh distribution of tree species among elevation is largely controlled by the density of over storey species and the pattern of regeneration can be described by the size distribution [33] as reported by Singh et al. Middle elevation sites had a lower number of species than lower and higher elevation sites. Lower elevation is easily assessable by men than others, so it is a little disturbed. Disturbed sites contained more species than undisturbed and moderately disturbed sites. Disturbances occurred either in the form of recurring soil erosion (natural) or anthropogenic disturbances such as grazing, lopping, surface burning and illegal cutting. A higher percentage of random and regular distribution reflects the greater magnitude of disturbance' such as grazing and lopping in natural forest stands. All the vegetation layers showed generally clumped type of distribution in the present study. The tree layer exhibited less clumped distribution at the disturbed sites than the undisturbed and moderately disturbed study sites. The distribution pattern of other vegetational layers did not show any distinct difference among the study sites. These findings supported the range reported by Risser and Rice [34] for temperate forests. The highest number of tree species (22) was recorded from Stand UTZ due to relatively open habitat which provided congenial environment for the growth of different species. Figure 4 shows the total density of tree species ranged between 1009 trees/ha (UTZ) to 1203 trees/ha (MTF). Study revealed that Quercus leucotricophora is the most dominant species of all stands. Oak (Qurecus spp) forests are most extensively distributed between the altitudes $1000 \mathrm{~m}$ to timberline and represent the climax stage, throughout the central Himalaya [35]. The result of the present study is pronounced that as well as the altitude is increase the tree diversity is also increase which is the result of above biotic disturbance and invention by new species on these lands.

\section{Conclusions}

Biological resources of the area are used by local people in various ways. The loss of biodiversity and degradation of forests in many places (especially near villages) can be attributed medicinal herb collection and unregulated grazing. Many resident species are expected to be endangered or threatened. The important flora needs protection, because of their scientific interest and rarity. To prevent deforestation, alternative sources of fuel and timber should be introduced. Programs that provide conservation education, initiate the sustainable use of the forests, and propagate multipurpose indigenous trees should be initiated. Less economic tree species showed higher population and regeneration where important tree species such as Taxus, Magnolia and Michelia showed less dominated 
due to the lopping and over exploitation of timber so the forest may convert into unnecessary bushy forest in near future. Higher densities of trees having less than $20 \mathrm{~cm} \mathrm{DBH}$ and basal area of tree species in our study suggest that forest in each site are in stage of growing and in state of regeneration. The diversity of tree species showed hump shape relation with elevation gradient. It is recommended that biological inventories with comprehensive flora and fauna biological databases should be prepared. Detailed ecological study of vegetation is needed for the development of conservation and management programs within the study area. The study suggests conservation strategies to protect woody species against anthropogenic pressures (for example, protection from or reducing the frequency and/or intensity of disturbance, especially woodcutting and bushfires).

\section{Acknowledgements}

This study was supported by ESON. We would like to thank the Central Department of Botany, Tribhuvan University, Nepal. We thank KCA for the permission to study. We also thank staff of KATH herbarium of Nepal for their support and local people in the study area. I would like to thank for Dr. Jyoti Prashad Gajurel for his continuous support and inspiration for the work.

\section{Conflicts of Interest}

The authors declare no conflicts of interest regarding the publication of this paper.

\section{References}

[1] Shakya, P.R., Adhikari, M.K., Rajbhandari, K.R., Chaudhary, R.P. and Shresth, K.K. (1997) Country Paper-Flora of Nepal. Presented at International Seminar-Cum-Workshop on Flora of Nepal, Kathmandu.

[2] Wilson, E.O. (1992) The Diversity of Life. Belknap Press, Havard University, Cambridge, MA.

[3] WCMC (1992) Global Biodiversity: Status of the Earth Living Resources. World Conservation Monitoring Center (WCMC). Chapman and Hall, London.

[4] Yonzon, P. (1996) Eastern Himalaya: Corridors and Climate Change. Habitat Himalaya, 13, No. 1

[5] Shrestha, K.K. and Ghimire, S.K. (1997) Kanchenjunga Conservation Area: Rich Protected Area of Nepal. Welcome Nepal, 5, 21-26.

[6] Fosberg, F.R. (1961) A Classification of Vegetation for General Purpose. Tropical Ecology, 2, 1-28.

[7] Vetaas, O.R. (1997) The Effect of Canopy Disturbance on Species Richness in a Central Himalayan Oak Forest. Plant Ecology, 132, 29-38. https://doi.org/10.1023/A:1009751219823

[8] Maskai, T., Tanaka, H., Tanouchi, H., Sakai, T. and Nakashizuka, T. (1999) Structure Dynamics and Disturbance Regime of Temperate Broad-Leaved Forest in Japan. Journal of Vegetation Science, 10, 805-814. https://doi.org/10.2307/3237305 
[9] Sheill, D. (1999) Tropical Forest Diversity, Environmental Changes and Species Augmentation: After Intermediate Disturbance Hypothesis. Journal of Vegetation Science, 10, 851-860. https://doi.org/10.2307/3237310

[10] Roberts, M.R. and Gilliams, F.S. (1995) Patterns and Mechanism of Plant Diversity in Forest Ecosystem. Implication for Forest Management. Ecological Application, 5, 696-697. https://doi.org/10.2307/2269348

[11] Bridson, D. and Forman, L. (1992) The Herbarium Handbook. Royal Botanic Gardens, Kew.

[12] Hooker, J.D. (1872-1897) The Flora of British India Vol. i-vii. Reev and Company, London.

[13] Collett, H. (1925) Flora Simlensis. A Handbook of flowering Plants of Simla and neighbourhood. Thacker, Spink. Co.

[14] Grierson, A.J.C. and Long, D.G. (1983-2001) Flora of Bhutan. Vol. 1, Part 1-3; Vol. 2, Part 1-3; Vol. 3, Part 1-3, Royal Botanical Garden Edinburgh and Royal Government of Bhutan.

[15] Stainton, A. and Polunin, O. (1987) Flowers of Himalaya. Oxford University Press, New Delhi.

[16] Stainton, A. (1988) Flowers of Himalaya: A Supplement. Oxford University Press, Oxford.

[17] Dahlen, J. (1993) Shivapuri Integrated Watershade Management Plan. FAO, Forest Dept., Nepal.

[18] Devlal, R. and Sharma, N. (2008) Altitudinal Changes in Dominance-Diversity and Species Richness of the Species in a Temperate Forest of Garhwal Himalayan. Life Science Journal, 5, 53-57.

[19] Kershaw, K.R. (1973) Quantitative and Dyanamic Plant Ecology. Edward Arnold Limited, London.

[20] Kershaw, K.R. (1973) Quantitative and Dynamic Plant Ecology. Edward Arnold Limited, London.

[21] Mishra R. (1968) Ecology Workbook. Oxford and IBH Publishing Co., Calcutta.

[22] Curtis J.T. (1959) The Vegetation of Wisconsin: An Ordination of Plant Communities. University of Wisconsin Press, Madison, 657.

[23] Shannon, C.E. and Wiener, W. (1963) The Mathematical Theory of Communication. University of Illinois Press, Urbana, $117 \mathrm{p}$.

[24] Simpson, E.H. (1949) The Measurement of Diversity. Nature, 163, 688. https://doi.org/10.1038/163688a0

[25] Barbour, M.G., Burk, J.H., Pitts, W.D., Gilliam, F.S. and Schwartz, M.W. (1999) Teresterial Plant Ecology. 3rd Edition, Benjamin/Cummings, Menlo Park, 649 p.

[26] Magurran, A.E. (2004) Measuring Biological Diversity. Blackwell Science Ltd., Oxford, $256 \mathrm{p}$.

[27] Siwakoti, M. and Verma, S.K. (1999) Plant Diversity of East Nepal: Flora of Plains of East Nepal. M/S Bishen Singh Mahendra Pal Singh, Deharadun.

[28] Visalakshi, N. (1995) Vegetation Analysis in Two Tropical Evergreen Forests in Southern India. Tropical Ecology, 36, 117-127.

[29] Tripathi, K.P. (2001) Ecology of a Rehabilitated Forest on Sodic Wasteland. Ph.D. Thesis, Lucknow University, Lucknow.

[30] Vetaas, O.R. (2002) The Effect of Environmental Factors on the Regeneration of Quercus semicarpifolia Forest in Central Himalaya, Nepal. Plant Ecology, 146, 
137-144. https://doi.org/10.1023/A:1009860227886

[31] Gautam, C.M. and Watanabe, T. (2005) Composition, Distribution and Diversity of Tree Species under Different Management System in the Hill Forests of Bharse Village, Gulmi District, Western Nepal. Himalayan Journal of Sciences, 3, 67-74. https://doi.org/10.3126/hjs.v3i5.464

[32] Ramirez-Marcial, N., Gonzalez-Espinosa, M. and Williams-Linera, G. (2001) Anthropogenic Disturbance and Tree Diversity in Montane Rain Forest in Chipas, Mexico. Forest Ecology and Management, 154, 311-326. https://doi.org/10.1016/S0378-1127(00)00639-3

[33] Glatzel, G. (1999) Historic Forest Use and Its Possible Implications to Recently Accelerated Tree Growth in Central Europe. In: Karjalainen, T., Spiecker, H. and Laroussinie, O., Eds., Causes and Consequences of Accelerating Tree Growth in Europe, European Forest Institute, 65-74.

[34] Singh, S.P. and Singh, J.S. (1986) Structure and Function of the Central Himalayan Oak Forests. Proceeding Indian Academy of Science, 96, 159-189.

[35] Risser, P.G. and Rice, E.I. (1971) Diversity in Tree Species in Oklahoma Upland Forests. Ecology, 52, 876-880. https://doi.org/10.2307/1936036

[36] Champion, H.G. and Seth, S.K. (1968) A Revised Survey of Forest Types of India. Manager of Publications, Delhi. 